\title{
The Cultivation of Chelidonium majus L. Increased the Total Alkaloid Content and Cytotoxic Activity Compared with Those of Wild-Grown Plants
}

\author{
Valerija Krizhanovska ${ }^{1}$, Inga Sile $\left.{ }^{1,2}{ }^{(}\right)$, Arta Kronberga ${ }^{3}$, Ilva Nakurte ${ }^{4}$, Ieva Mezaka ${ }^{4}$, Maija Dambrova ${ }^{1,5}{ }^{(D)}$, \\ Osvalds Pugovics ${ }^{1}$ and Solveiga Grinberga ${ }^{1, *}$
}

check for updates

Citation: Krizhanovska, V.; Sile, I.; Kronberga, A.; Nakurte, I.; Mezaka, I.; Dambrova, M.; Pugovics, O.; Grinberga, S. The Cultivation of Chelidonium majus L. Increased the Total Alkaloid Content and Cytotoxic Activity Compared with Those of Wild-Grown Plants. Plants 2021, 10, 1971. https://doi.org/10.3390/ plants10091971

Academic Editor: Sebastian Granica

Received: 16 August 2021

Accepted: 15 September 2021

Published: 21 September 2021

Publisher's Note: MDPI stays neutral with regard to jurisdictional claims in published maps and institutional affiliations.

Copyright: (C) 2021 by the authors Licensee MDPI, Basel, Switzerland. This article is an open access article distributed under the terms and conditions of the Creative Commons Attribution (CC BY) license (https:// creativecommons.org/licenses/by/ $4.0 /)$.
1 Latvian Institute of Organic Synthesis, 21 Aizkraukles Str., LV-1006 Riga, Latvia; valerija@osi.lv (V.K.); inga.sile@farm.osi.lv (I.S.); maija.dambrova@farm.osi.lv (M.D.); osvalds@osi.lv (O.P.)

2 Department of Dosage Form Technology, Riga Stradins University, 16 Dzirciema Str., LV-1007 Riga, Latvia

3 Field and Forest, SIA, 2 Izstades Str., LV-4126 Priekuli Parish, Cēsis County, Latvia; arta.kronberga@fieldandforest.lv

4 Institute for Environmental Solutions, “Lidlauks”, LV-4126 Priekul, Parish, Cēsis County, Latvia; ilva.nakurte@vri.lv (I.N.); ieva.mezaka@vri.lv (I.M.)

5 Department of Pharmaceutical Chemistry, Riga Stradins University, 16 Dzirciema Str., LV-1007 Riga, Latvia

* Correspondence: solveiga@osi.lv

\begin{abstract}
The effect of cultivation practises on both the phytochemical profile and biological activity of aqueous ethanol extracts of Chelidonium majus L. was studied. Extracts were prepared from aerial parts of the same plant population collected in the wild and grown under organic farming conditions. Both qualitative and quantitative analyses of alkaloids and flavonoid derivatives were performed by LC/MS methods, and the cytotoxicity of lyophilised extracts was studied in B16F10, HepG2, and CaCo-2 cells. Coptisine was the dominant alkaloid of extracts prepared from wild-grown plants, whereas after cultivation, chelidonine was the most abundant alkaloid. The total alkaloid content was significantly increased by cultivation. Ten flavonol glycoconjugates were identified in C. majus extracts, and quantitative analysis did not reveal significant differences between extracts prepared from wild-grown and cultivated specimens. Treatment with C. majus extracts resulted in a dose-dependent increase in cytotoxicity in all three cell lines. The extracts prepared from cultivated specimens showed higher cytotoxicity than the extracts prepared from wild-grown plants. The strongest cytotoxic effect of cultivated C. majus was observed in B16-F10 cells $\left(\mathrm{IC}_{50}=174.98 \pm 1.12 \mu \mathrm{g} / \mathrm{mL}\right)$. Cultivation-induced differences in the phytochemical composition of C. majus extracts resulted in significant increases in the cytotoxic activities of the preparations.
\end{abstract}

Keywords: Chelidonium majus; alkaloids; flavonoids; LC/MS analysis; cytotoxic activity

\section{Introduction}

Greater celandine, Chelidonium majus L. (Papaveraceae Juss), is a valuable medicinal plant that is widely distributed throughout Europe, Asia, Northwest Africa, and North America [1]. In Latvia, it is considered a native species occurring throughout the country from solitarily specimens to dense growths [2]. In traditional medicine, C. majus has been used to treat bile and liver disorders [3]. Fresh latex from plants has been used externally for the treatment of warts, corns, fungal infections, eczema, and tumours of the skin [4,5]. In Latvian folklore materials, fresh latex and tea made from C. majus were reported to be used for treating diarrhoea, eye problems, and skin diseases such as lichen and warts [6]. The treatment of ophthalmological problems and gastrointestinal and skin disorders are mentioned among many other ethnobotanical studies across Europe [7-10]. The European Medicines Agency (EMA) has proposed two possible therapeutic indications in the monograph on Chelidonii herba: for symptomatic relief of digestive disorders such as dyspepsia and flatulence (oral intake), as well as for treatment of warts, calluses, and 
corns (cutaneous use) [11]. However, these indications were not supported due to a lack of information on clinical safety. From a research point of view, this plant is still very interesting because it is widely used in folk medicine, but it has not yet acquired the status of an officially approved and evidence-based herbal medicine.

This species is known to produce a broad range of secondary metabolites, ensuring its therapeutic properties. The main constituents of $C$. majus responsible for biological properties are isoquinoline alkaloids such as chelidonine, chelerythrine, sanguinarine, coptisine, berberine, allocryptopine, and protopine [1]. They are reported to have anti-inflammatory, antimicrobial, antibacterial, antiviral, immunomodulatory, anticancer, choleretic, hepatoprotective, and analgesic properties [1,3]. C. majus alkaloids are a subject of interest due to their cytotoxic effects against various types of cancer cell lines [12-14]. The well-known product $\mathrm{Ukrain}^{\circledR}$, a preparation consisting of a mixture of C. majus alkaloids, is marketed for its anticancer properties. However, many previous clinical studies are considered untrustworthy [15]. Most in vitro anticancer activity studies of C. majus refer to sanguinarine, chelidonine, chelerythrine, and berberine. Sanguinarine, which interacts strongly with DNA, has been shown to be the most potent anticancer agent obtained from C. majus. The IC50 values of sanguinarine in leukaemia cell lines are reported to be up to $0.10 \mu \mathrm{M}$ [12] and $0.2 \mu \mathrm{M}$ in human keratinocyte (HaCaT) cell lines [14]. Chelerythrine, berberine, and chelidonine are also active, but are less potent as cytostatic agents [12].

Comprehensive reports on the alkaloid profile of C. majus [16-19] are available. More than 50 alkaloids have been detected in greater celandine [17,20]. Quantitative analyses of the main alkaloids chelerythrine, sanguinarine, and coptisine in C. majus extracts were performed by HPLC-DAD and LC-MS/MS, and tentative identification of minor alkaloids was performed with data from the literature $[16,19,21-23]$. In contrast, data on flavonoid composition and content in C. majus are fragmented and mainly qualitative. Grosso et al. [16] quantified the flavonoid content with HPLC-DAD for the first time, and MRM methods were used for the determination of quercetin and phenolic acids [23].

Greater celandine, like other wild plants, shows interesting features with potential commercial viability. The market demand for biologically active ingredients from plants is increasing, and the cultivation of medicinal plants offers several benefits over collection of wild plants, e.g., reliable supply, standardised and improved production, and certainty of botanical identity. It is well known that the content of biologically active components of celandine is significantly affected by growing conditions [1,24]. Therefore, it is important to assess the influence of cultivation practices (growing in the wild or under organic farming conditions) on the phytochemical composition of $C$. majus populations.

The aim of this study was to investigate how growing conditions affect both the phytochemical compositions and cytotoxic activities of aqueous ethanol extracts of $C$. majus. Aerial parts of wild populations of $C$. majus originating from different regions of Latvia were harvested. Plantlets from the same wild populations were planted and cultivated under organic farming conditions. Aqueous ethanolic extracts were prepared from both wild-grown and cultivated plants. High-resolution mass spectrometry was applied for the identification of phytochemical compounds, and quantitative analyses of major components were performed by UPLC-MS/MS. CaCo-2, HepG2, and B16-F10 cell lines were selected for cytotoxicity analysis because in traditional medicine, aerial parts of C. majus have often been used to treat gastric and liver diseases, and locally for various skin disorders [1,17]. The cytotoxic activities of the lyophilised extracts were determined in these three cancer cell lines.

\section{Results and Discussion}

\subsection{Alkaloid Profile and Quantitative Analysis of Aqueous Ethanol C. majus Extracts}

LC/MS-TOF analyses of aqueous ethanol C. majus extracts revealed the presence of 12 alkaloids. The identities of chelidonine, sanguinarine, and chelerythrine were confirmed with available reference standards. Tentative identification of other alkaloids was per- 
formed by comparison of their chromatographic retention times and detected $\mathrm{m} / \mathrm{z}$ values with literature data $[19,25]$. A summary of the identification results is shown in Table 1.

Table 1. List of tentatively identified alkaloids in the ethanol extracts of aerial parts of C. majus.

\begin{tabular}{|c|c|c|c|c|}
\hline RT, min & $\mathbf{m} / \mathbf{z}$ & Compound & MW (Monoisotopic) & Calculated Elemental Composition \\
\hline 18.02 & 354.134 & Protopine ${ }^{1}$ & 353.126 & $\mathrm{C}_{20} \mathrm{H}_{19} \mathrm{NO}_{5}$ \\
\hline 18.81 & 354.133 & Chelidonine & 353.126 & $\mathrm{C}_{20} \mathrm{H}_{19} \mathrm{NO}_{5}$ \\
\hline 19.00 & 370.163 & Allocryptopine ${ }^{1}$ & 369.158 & $\mathrm{C}_{21} \mathrm{H}_{23} \mathrm{NO}_{5}$ \\
\hline 19.09 & 320.092 & Coptisine ${ }^{1}$ & 320.092 & $\mathrm{C}_{19} \mathrm{H}_{14} \mathrm{NO}_{4}^{+}$ \\
\hline 20.2 & 370.165 & Allocryptopine ${ }^{1}$ & 369.158 & $\mathrm{C}_{21} \mathrm{H}_{23} \mathrm{NO}_{5}$ \\
\hline 20.33 & 340.118 & Norchelidonine 1 & 339.111 & $\mathrm{C}_{19} \mathrm{H}_{17} \mathrm{NO}_{5}$ \\
\hline 20.56 & 340.153 & Canadine ${ }^{1}$ & 339.147 & $\mathrm{C}_{20} \mathrm{H}_{21} \mathrm{NO}_{4}$ \\
\hline 21.05 & 340.118 & Norchelidonine ${ }^{1}$ & 339.111 & $\mathrm{C}_{19} \mathrm{H}_{17} \mathrm{NO}_{5}$ \\
\hline 21.28 & 332.091 & Sanguinarine & 332.092 & $\mathrm{C}_{20} \mathrm{H}_{14} \mathrm{NO}_{4}^{+}$ \\
\hline 21.87 & 336.122 & Berberine ${ }^{1}$ & 336.124 & $\mathrm{C}_{20} \mathrm{H}_{18} \mathrm{NO}_{4}^{+}$ \\
\hline $23.46^{2}$ & 348.122 & Chelerythrine & 348.124 & $\mathrm{C}_{21} \mathrm{H}_{18} \mathrm{NO}_{4}^{+}$ \\
\hline $23.46^{2}$ & 382.128 & $\begin{array}{l}\text { 6,10-Dihydroxyl } \\
\text { chelerythrine }^{3}\end{array}$ & 382.129 & $\mathrm{C}_{21} \mathrm{H}_{20} \mathrm{NO}_{6}^{+}$ \\
\hline
\end{tabular}

${ }^{1}[19],{ }^{2}$ overlapping chromatographic signals, ${ }^{3}$ [25], bold-identified by comparison with reference compounds.

The results of quantitative determinations of major alkaloids revealed coptisine as the predominant compound in C. majus extracts prepared from wild-grown celandine (Table 2, Supplementary Materials Table S1).

Table 2. Content of alkaloids ( $\mu \mathrm{g} / \mathrm{g}$ of dry material) in the ethanol extracts of aerial parts of wildgrown and cultivated C. majus.

\begin{tabular}{cccc}
\hline \multirow{2}{*}{ Compound } & \multicolumn{2}{c}{ Average Alkaloid Content (n = 5) } & \multirow{2}{*}{$\boldsymbol{p}$ Value } \\
\cline { 2 - 3 } & Wild 2019 & Cultivated 2020 & \\
\hline Sanguinarine & $1.9 \pm 2.1$ & $12.8 \pm 3.6$ & 0.0004 \\
Chelerythrine & $3.5 \pm 1.3$ & $17.5 \pm 8.5$ & 0.007 \\
Chelidonine & $63.6 \pm 35.4$ & $252.2 \pm 133.2$ & 0.02 \\
Coptisine $^{1}$ & $138.5 \pm 35.6$ & $143.5 \pm 32.2$ & 0.8 \\
Berberine $^{1}$ & $9.4 \pm 6.6$ & $12.8 \pm 8.4$ & 0.6 \\
Allocryptopine & $5.2 \pm 3.0$ & $11.9 \pm 7.4$ & 0.1 \\
Total Content $^{1}$ & 222.0 & 450.6 & 0.02 \\
\hline
\end{tabular}

${ }^{1}$ Coptisine, berberine, and allocryptopine quantified as chelidonine.

Coptisine, as the predominant alkaloid, was also found by Sárközi et al. [21]; however, the extracts in their study were prepared using methylene chloride. Chelerythrine and sanguinarine were found to be the dominant alkaloids in methanol extracts [19]. In aqueous ethanol extracts, coptisine was found to be the dominant alkaloid; moreover, an increase in ethanol content from $25 \%$ to $45 \%$ resulted in a more than fivefold increase in coptisine recovery [26].

Our study shows that the chelidonine content in extracts of cultivated specimens was approximately four times higher than that in wild-grown plant preparations, and chelidonine became the dominant alkaloid. It should be noted that the variability of chelidonine content in extracts prepared from both cultivated and wild-grown C. majus specimens was very high (RSD $>50 \%$ in both cases, $n=5$, Supplementary Materials Table S1). The total content of alkaloids in extracts prepared from cultivated C. majus specimens was significantly higher than that in extracts prepared from wild-grown C.majus specimens (Table 2). The contents of both sanguinarine and chelerythrine were significantly increased in extracts prepared from cultivated C. majus specimens. Coptisine, berberine, and allocryptopine contents also showed increasing tendencies in extracts of cultivated $C$. majus plants; however, the concentration variability between individual samples was still very high, and the differences were not statistically significant. 
Wide variation in the alkaloid content in C. majus has been reported previously by other authors $[18,27,28]$. Many factors, such as genotype, plant age, developmental phases, harvesting time, and environmental conditions, can affect the alkaloid content in raw plant material.

\subsection{Flavonoid Profile and Quantitative Analysis of Aqueous Ethanol C. majus Extracts}

C. majus contains minor amounts of quercetin, kaempferol, and isorhamnetin glycoconjugates [16,29]. Recently, a small phenolic acids content [23] was discovered. Several studies $[18,24]$ have focused on the total phenolics content or total flavonoids content. Mass spectrometry was sporadically applied for the identification of individual compounds [16].

To achieve nontarget identification of flavonoid derivatives, we screened the corresponding aglycone masses of quercetin, isorhamnetin, and kaempferol on an HRMS instrument and then performed MRM analyses on a tandem mass spectrometer (Supplementary Materials Figure S1). The identified key flavonols quercetin, kaempferol, and isorhamnetin were found to be present in various glycosylated forms. In contrast to roots showing the presence of only quercetin aglycone [23], in aerial parts we identified 10 mono-, di-, and triglycosides of flavonols, as shown in Table 3.

Table 3. List of tentatively identified flavonoids in the ethanol extracts of aerial parts of C. majus.

\begin{tabular}{|c|c|c|c|c|c|c|c|}
\hline Peak \# & RT, min & $\begin{array}{l}\text { Characteristic } \\
\text { ions }{ }^{1} \mathrm{ESI}^{+}, \mathrm{m} / \mathrm{z}\end{array}$ & $\begin{array}{c}\text { Characteristic } \\
\text { ions }{ }^{1} \mathrm{ESI}^{-}, \mathrm{m} / \mathrm{z}\end{array}$ & Compound & $\begin{array}{l}\text { MW } \\
\text { (Monoiso- } \\
\text { topic) }\end{array}$ & $\begin{array}{c}\text { Calculated } \\
\text { Elemental } \\
\text { Composition }\end{array}$ & $\begin{array}{c}\text { Parent Scan of } \\
\text { Aglycone Fragment } \\
\text { Ion, } \mathrm{m} / \mathrm{z}\end{array}$ \\
\hline 1 & 11.2 & 627.144 & & $\begin{array}{l}\text { Quercetin } \\
\text { Triglycoside }\end{array}$ & 772.206 & $\mathrm{C}_{33} \mathrm{H}_{40} \mathrm{O}_{21}$ & $773,627,465(303)^{3}$ \\
\hline 2 & 13.0 & & 755.201 & $\begin{array}{l}\text { Kaempferol } \\
\text { Triglycoside }\end{array}$ & 756.211 & $\mathrm{C}_{33} \mathrm{H}_{40} \mathrm{O}_{20}$ & $757,611,449$ (287) \\
\hline 3 & 13.6 & 479.119 & & $\begin{array}{l}\text { Isorhamnetin } \\
\text { Triglycoside }\end{array}$ & 786.222 & $\mathrm{C}_{34} \mathrm{H}_{42} \mathrm{O}_{21}$ & $787,641,479(317)$ \\
\hline 4 & 16.8 & 611.159 & 609.143 & $\begin{array}{c}\text { Quercetin } \\
\text { 3-O-Rutinoside }\end{array}$ & 610.153 & $\mathrm{C}_{27} \mathrm{H}_{30} \mathrm{O}_{16}$ & $611,465(303)$ \\
\hline 5 & 17.0 & 465.101 & & $\begin{array}{c}\text { Quercetin } \\
\text { 3-O-Galactoside }\end{array}$ & 464.100 & $\mathrm{C}_{21} \mathrm{H}_{20} \mathrm{O}_{12}$ & $465(303)$ \\
\hline 6 & 17.4 & 287.056 & 593.147 & $\begin{array}{l}\text { Kaempferol } \\
\text { Diglycoside }\end{array}$ & 594.158 & $\mathrm{C}_{27} \mathrm{H}_{30} \mathrm{O}_{15}$ & $595,449(303)$ \\
\hline 7 & 18.4 & 287.054 & 593.147 & $\begin{array}{c}\text { Kaempferol } \\
\text { 3-O-Rutinoside }\end{array}$ & 594.101 & $\mathrm{C}_{27} \mathrm{H}_{30} \mathrm{O}_{15}$ & $595,449(287)$ \\
\hline 8 & 18.8 & 449.104 & 447.089 & $\begin{array}{l}\text { Kaempferol } \\
\text { Glucoside }\end{array}$ & 448.101 & $\mathrm{C}_{21} \mathrm{H}_{20} \mathrm{O}_{11}$ & $449(287)$ \\
\hline 9 & 19.0 & 625.173 & 623.158 & $\begin{array}{l}\text { Isorhamnetin } \\
\text { 3-O-Rutinoside }\end{array}$ & 624.169 & $\mathrm{C}_{28} \mathrm{H}_{32} \mathrm{O}_{16}$ & $626,279(317)$ \\
\hline 10 & 19.4 & 479.119 & 477.102 & $\begin{array}{l}\text { Isorhamnetin } \\
\text { Glycoside }\end{array}$ & 478.111 & $\mathrm{C}_{22} \mathrm{H}_{22} \mathrm{O}_{12}$ & 479 (317) \\
\hline
\end{tabular}

${ }^{1}$ HRMS data, ${ }^{2}$ mass difference within $\pm 5 \mathrm{mDa},{ }^{3} \mathrm{~m} / \mathrm{z}$ of aglycone fragment in brackets, bold-identified by comparison with reference compounds.

Three intense peaks for flavonol 3-O-diglycosides consisting of both rhamnoside and glucoside fragments were observed. Peak 4 yielded a precursor ion with an $\mathrm{m} / \mathrm{z} 611$ [M $+\mathrm{H}]^{+}$along with a fragment with $\mathrm{m} / \mathrm{z} 465$ for the loss of rhamnosyl, indicating that it is quercetin 3-O-rhamnosylglucoside, while peaks 7 and 9 with similar fragmentation patterns $(595 \rightarrow 449$ and $625 \rightarrow 479)$ were identified as kaempferol 3-O-rhamnosylglucoside and isorhamnetin 3-O-rhamnosylglucoside. The identities were confirmed by comparison with reference standards.

Along with monoglycosides and diglycosides (peaks 4-10), carbohydrate residues with three saccharide moieties were identified in extracts. Peak 2 showed a precursor ion at $\mathrm{m} / \mathrm{z} 757[\mathrm{M}+\mathrm{H}]^{+}\left(\mathrm{C}_{33} \mathrm{H}_{40} \mathrm{O}_{20}\right)$, and its MS/MS spectrum presented a product ion at $\mathrm{m} / \mathrm{z} 611$ attributed to the elimination of a glycosyl residue and a product ion at $\mathrm{m} / \mathrm{z}$ 449 produced after loss of a rutinoside residue. Based on aglycone formation at $\mathrm{m} / \mathrm{z}$ 287, this compound was tentatively identified as kaempferol 3-O-rhamnosylglycoside-7-Oglucoside [30]. Similarly, quercetin 3-O-triglycoside consisting of one rhamnosidylglycoside 
and one glucoside (peak 1) and isorhamnetin 3-O-rhamnosylglycoside-7-O-glucoside (peak 3) were identified. The identification of peak 3 was based on the MRM parent scan, as HR full scan mass spectra did not yield protonated molecular ions. These three glycosides (peaks 1, 2, and 3) were formed from the same carbohydrates attached to the same positions of the three different flavonols and have not been previously reported in C. majus.

Two peaks with molecular masses equivalent to that of kaempferol diglycoside were detected (peaks 6 and 7). Although both molecular and aglycone ions coincided, retention times were different. The later eluting peak (7) was identified as kaempferol-3-rutinose by comparison with the reference compound.

Quantitative analyses of flavonoids showed the predominance of rutinoside-type glycoconjugates (Table 4, Supplementary Materials Table S2), similar to the findings of Grosso et al. [16] and Parvu et al. [29]. Quercetin 3-O-rutinoside (rutin) was the predominant compound in extracts prepared from both wild-grown and cultivated C. majus specimens. The next most abundant flavonol glycosides were isorhamnetin 3-O-rutinoside and kaempferol 3-O-rutinoside. The total flavonol glycoside content was slightly higher in extracts prepared from cultivated C. majus specimens; however, the major contribution was the increase in rutin content, and the changes were not statistically significant.

Table 4. Content of flavonoids ( $\mu \mathrm{g} / \mathrm{g}$ of dry material) in the ethanol extracts of aerial parts of wild-grown and cultivated C. majus.

\begin{tabular}{cccc}
\hline Compound & \multicolumn{2}{c}{ Average Flavonoid Content (n= 5) } & $p$ Value \\
& Wild 2019 & Cultivated 2020 & \\
\hline Kaempferol & $13.1 \pm 9.2$ & $6.9 \pm 4.2$ & 0.2 \\
Isorhamnetin & $8.8 \pm 6.7$ & $4.0 \pm 1.6$ & 0.2 \\
Quercitrin & $1.4 \pm 1.2$ & $2.0 \pm 0.9$ & 0.4 \\
Isorhamnetin 3-O-Rutinoside & $1612.7 \pm 722.9$ & $1857.2 \pm 326.0$ & 0.5 \\
Kaempferol 3-O-Rutinoside & $653.8 \pm 377.4$ & $600.7 \pm 216.4$ & 0.8 \\
Quercetin 3-O-Rutinoside & $3007.2 \pm 1270.1$ & $4385.1 \pm 1150.8$ & 0.1 \\
Quercetin 3-O-Galactoside & $220.2 \pm 269.9$ & $195.9 \pm 114.0$ & 0.9 \\
${\text { Kaempferol Glucoside }{ }^{1}}^{\text {Total }}$ & $135.9 \pm 130.8$ & $53.5 \pm 12.9$ & 0.2 \\
& 5653.1 & 7105.3 & 0.3 \\
\hline
\end{tabular}

1. Kaempferol glucoside-quantified as luteolin 7-O-glucoside.

\subsection{Cytotoxic Activity of Extracts from C. majus}

The cytotoxic activities of extracts towards B16-F10, HepG2, and CaCo-2 cell lines were evaluated by determination of $\mathrm{IC}_{50}$ values in the MTT assay. Treatment with $C$. majus extracts resulted in dose-dependent increases in cytotoxicity in all three cell lines (Figure 1). The strongest cytotoxic effect of C. majus was observed in B16-F10 cells. The $\mathrm{IC}_{50}$ values of the cultivated samples on B16-F10 cells ranged between $174.98 \pm 1.12 \mu \mathrm{g} / \mathrm{mL}$ and $318.42 \pm$ $1.08 \mu \mathrm{g} / \mathrm{mL}$. HepG2 and CaCo-2 cells were less sensitive than the melanoma cells, and the IC50 values of the cultivated samples ranged between $226.46 \pm 1.66 \mu \mathrm{g} / \mathrm{mL}$ and $448.75 \pm$ $1.34 \mu \mathrm{g} / \mathrm{mL}$ and from $291.07 \pm 1.10 \mu \mathrm{g} / \mathrm{mL}$ to $406.44 \pm 1.08 \mu \mathrm{g} / \mathrm{mL}$, respectively (Table 5).

The cytotoxicity data of this study showed activities for aqueous ethanol extracts that are lower than those previously reported. Thus, the $\mathrm{IC}_{50}$ value for the methanol extract on CaCo-2 cells was $166.06 \pm 15.71 \mu \mathrm{g} / \mathrm{mL}$, and that on HepG-2 cells was $144.81 \pm$ $15.03 \mu \mathrm{g} / \mathrm{mL}$ [31]. In the study by Fadhil, [32], the cytotoxic effect $\left(\mathrm{IC}_{50}=282.86 \mu \mathrm{g} / \mathrm{mL}\right)$ of $C$. majus on HepG-2 cells was in line with the present results. C. majus cultivated under controlled environmental conditions exhibited higher cytotoxic activity against all studied cell lines. 
B16-F10

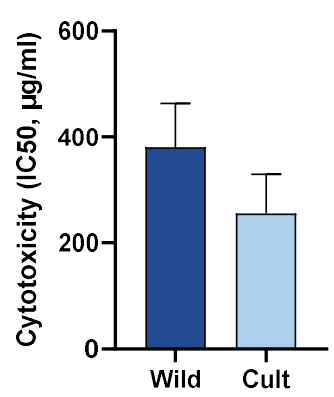

HepG2

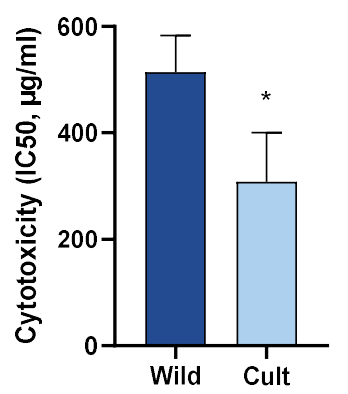

CaCo-2

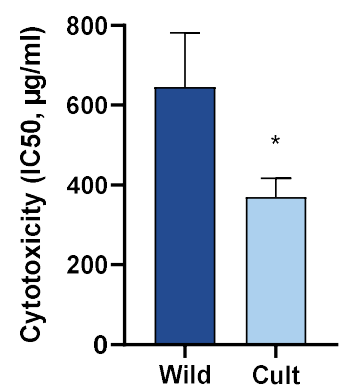

Figure 1. Differences in cytotoxic activities between cultivated and wild-grown C. majus on B16-F10, HepG2, and CaCo-2 cell lines measured by MTT assay. Values are the mean $\pm \mathrm{SD}(n=5)$. Differences between the measurements were tested using the Mann-Whitney U-test. * Significantly different from wild-grown C. majus $(p<0.05)$.

Table 5. Inhibitory effects on the growth of human hepatocellular carcinoma (HepG2), murine melanoma (B16-F10), and human colorectal adenocarcinoma (CaCo-2) cells.

\begin{tabular}{cccc}
\hline \multirow{2}{*}{ Sample } & \multicolumn{3}{c}{ IC $_{\mathbf{5 0}}(\boldsymbol{\mu g} / \mathbf{m L}) \pm \mathbf{S D}$} \\
\cline { 2 - 4 } & HepG2 & B16-F10 & CaCo-2 \\
\hline Wild 2019 & & & \\
CHM01 & $422.67 \pm 1.09$ & $264.85 \pm 1.13$ & $>500$ \\
CHM02 & $>500$ & $354.81 \pm 1.22$ & $>500$ \\
CHM03 & $>500$ & $496.59 \pm 1.05$ & $>500$ \\
CHM04 & $>500$ & $389.94 \pm 1.12$ & $>500$ \\
CHM05 & $461.32 \pm 1.13$ & $394.46 \pm 1.08$ & \\
Cultivated 2020 & & & $361.41 \pm 1.84$ \\
CHM01 & $351.56 \pm 1.38$ & $279.25 \pm 1.08$ & $291.07 \pm 1.10$ \\
CHM02 & $241.55 \pm 1.22$ & $174.98 \pm 1.12$ & $406.44 \pm 1.08$ \\
CHM03 & $272.27 \pm 1.16$ & $325.84 \pm 1.20$ & $389.94 \pm 1.20$ \\
CHM04 & $226.46 \pm 1.66$ & $318.42 \pm 1.08$ & $400.87 \pm 1.18$ \\
CHM05 & $448.75 \pm 1.34$ & $180.30 \pm 1.54$ &
\end{tabular}

The results of the present study showed that the cytotoxic effect in different cell lines varies depending on the alkaloid assessed. In experiments with HepG2 cells treated with various $C$. majus extracts, the strongest correlation was between the $\mathrm{IC}_{50}$ values and the contents of chelerythrine, sanguinarine, and chelidonine. In the case of B16-F10 cells, there was a correlation between the $\mathrm{IC}_{50}$ values and sanguinarine, chelidonine, and total alkaloid contents. Furthermore, the $\mathrm{IC}_{50}$ values for $\mathrm{CaCo}-2$ were correlated with the sanguinarine, chelerythrine, allocryptopine, and total alkaloid contents (Supplementary Materials Figure S2). Although the amount of chelidonine differed by up to four times between cultured and wild-grown C. majus samples, this was not clearly reflected in the biological activity results. Our data provide additional evidence that some alkaloids, such as chelerythrine, sanguinarine, and berberine, are more important in causing apoptosis or stopping the proliferation of cancer cells. Unlike the previously mentioned alkaloids, chelidonine is a weak DNA intercalating agent and does not cause lethal mutations or DNA damage $[1,33]$. This relationship is very well demonstrated in the study [33], where all these substances were tested on different cancer cells and chelerythrine, sanguinarine, and berberine showed significantly higher cytotoxicity. In human pharyngeal squamous carcinoma cells ( $\mathrm{FaDu}$ ), the difference between the $\mathrm{IC}_{50}$ values of sanguinarine and chelidonine was more than 500 times [33]. In our study, the cytotoxic activities of wild-grown and cultivated C. majus extracts were evaluated for the first time in the B16-F10, HepG2, and CaCo-2 cell lines. Our results confirmed the cytotoxicity of $C$. majus extracts towards the studied cell lines, which 
indicates the usefulness of compounds found in the extracts for the treatment of different cancer types.

\section{Materials and Methods}

\subsection{Chemicals and Reagents}

HPLC gradient grade acetonitrile and formic acid were purchased from Sigma-Aldrich (Schnelldorf, Germany). The reference substances sanguinarine, chelerythrine, and chelidonine were purchased from Biosynth Carbosynth (Compton, UK), Alfa Aesar Chemicals (Heysham, UK), and Cayman Chemical (Ann Arbor, MI, USA), respectively. All flavonoid reference substances were purchased from PhytoLab (Vestenbergsgreuth, Germany).

\subsection{Plant Materials and Preparation of Aqueous Ethanol Extracts}

Aerial parts from five populations of Chelidonium majus were collected from the wild at the flowering stage (hereafter referred to as "wild") for chemical analysis and biological activity testing during May 2019 (Supplementary Materials Table S3). Voucher specimens were deposited at the Institute for Environmental Solutions (IES) in Latvia under codes CHM01, CHM02, CHM03, CHM04, and CHM05. Ten randomly selected plantlets were also collected from the same five populations in 2019 and planted in an organically certified experimental field of IES (57 $19^{\prime} 11.7^{\prime \prime} \mathrm{N} 25^{\circ} 19^{\prime} 18.8^{\prime \prime} \mathrm{E}, 115 \mathrm{~m}$ altitude). The plot size was $0.8 \mathrm{~m}^{2}$, and the plant spacing was $0.2 \times 0.5 \mathrm{~m}$. A year later, aerial parts were collected during the flowering stage from the same populations in the experimental field (hereafter referred to as "cultivated"). The collected plant material was dried at $55^{\circ} \mathrm{C}$ for $14-29 \mathrm{~h}$, and then the plant material was powdered. Powdered dried samples of $C$. majus were macerated with $70 \%$ ethanol solution in water at 1:10 w/v. Prepared solutions were incubated for 7 days in a dark, cool place and frequently shaken until extraction of the plant material was completed. Afterwards, the material was pressed, and the remaining solid was squeezed to remove all remaining solvent. The obtained solutions were clarified by decantation and centrifugation.

\subsection{Preparation of Lyophilised Extracts}

For the biological activity assays, the aqueous ethanol extracts were concentrated with a rotary evaporator and further lyophilised. The obtained powder was labelled and stored in a refrigerator at $-20{ }^{\circ} \mathrm{C}$ prior to further analysis.

In vitro experiments with $C$. majus extracts were carried out using lyophilised plant material dissolved in dimethyl sulfoxide (DMSO). The final concentration of DMSO in each well did not exceed $0.5 \%(\mathrm{v} / \mathrm{v})$.

\subsection{HRMS Analysis}

The plant extracts were analysed on a Shimadzu LCMS hybrid IT-TOF system combined with a Nexera X2 UPLC system. An Acquity UPLC BEH C18 $(2.1 \times 150$ mm, $1.7 \mu \mathrm{m}$ particle size) column was used with a flow rate of $0.4 \mathrm{~mL} / \mathrm{min}$. The column oven was set at $40{ }^{\circ} \mathrm{C}$, and the sample injection volume was $1 \mu \mathrm{L}$. The mobile phase consisted of a combination of A ( $0.1 \%$ formic acid in water) and B (acetonitrile). Gradient: $2 \% \mathrm{~B}, 1 \mathrm{~min}-2 \% \mathrm{~B}$, $4 \mathrm{~min}-5 \% \mathrm{~B}, 14 \mathrm{~min}-15 \% \mathrm{~B}, 36 \mathrm{~min}-50 \% \mathrm{~B}, 48 \mathrm{~min}-98 \% \mathrm{~B}, 55 \mathrm{~min}-98 \% \mathrm{~B}, 58 \mathrm{~min}-2 \%$ $\mathrm{B}, 60 \mathrm{~min}-2 \% \mathrm{~B}$.

The adjusted operating parameters of the mass spectrometer were set as follows: detector voltage $-1.5 \mathrm{kV}$, nebulizing gas (N2) flow- $1.5 \mathrm{~mL} / \mathrm{min}$, mass scan range $(\mathrm{m} / \mathrm{z})$ -120 to 1000 , and ion accumulation time-10 ms. LCMSsolution software was used to process LCMS data. UV/Vis spectra were recorded over the range $190 \mathrm{~nm}$ to $650 \mathrm{~nm}$.

Aqueous ethanol extracts of dried plant material were injected into the chromatographic system without further processing. 


\subsection{UPLC-MS/MS Analysis of Alkaloids}

UPLC separation of target compounds in plant extracts was performed on an Acquity BEH C18 column $(2.1 \times 50 \mathrm{~mm}, 1.7 \mu \mathrm{m}$, Waters $)$ using a Waters Acquity UPLC system. A linear gradient from $5 \%$ acetonitrile in $0.1 \%$ aqueous formic acid to $98 \%$ acetonitrile was applied over $5 \mathrm{~min}$. A Xevo TQ-Smicro tandem mass spectrometer (Waters) in positive electrospray mode was used for quantification. Multiple reaction monitoring (MRM) parameters are detailed in Supplementary Materials Table S4.

Aqueous ethanol extracts were diluted 10 or 100 times with $70 \%$ ethanol before MRM analysis. Calibration concentrations ranged from $1 \mathrm{ng} / \mathrm{mL}$ to $250 \mathrm{ng} / \mathrm{mL}$ for all analytes.

\subsection{UPLC-MS/MS Analysis of Flavonoids}

UPLC separation of flavonoid glycoconjugates in plant extracts was performed on an Acquity BEH C18 column $(2.1 \times 100 \mathrm{~mm}, 1.7 \mu \mathrm{m}$, Waters $)$ using a Waters Acquity UPLC system. A linear gradient from $5 \%$ acetonitrile in $0.1 \%$ aqueous formic acid to $98 \%$ acetonitrile was applied over $12 \mathrm{~min}$. A Xevo TQ-Smicro tandem mass spectrometer (Waters) in positive electrospray mode was used for quantification. Multiple reaction monitoring (MRM) parameters are detailed in Supplementary Materials Table S5. Aqueous ethanol extracts were diluted 100 times with reserpine (internal standard) solution $(10 \mathrm{ng} / \mathrm{mL})$ in $70 \%$ ethanol before MRM analyses. Calibration concentrations ranged from $50 \mathrm{ng} / \mathrm{mL}$ to $10 \mu \mathrm{g} / \mathrm{mL}$ for all analytes.

\subsection{Cell Culture}

The B16-F10 murine melanoma cell line (CRL-6475 $\left.{ }^{\mathrm{TM}}\right)$, HepG2 human hepatocellular carcinoma cell line $\left(\mathrm{HB}-8065^{\mathrm{TM}}\right)$, and $\mathrm{CaCo}-2$ human colorectal adenocarcinoma cell line (HTB-37 ${ }^{\mathrm{TM}}$ ) were purchased from $\mathrm{ATCC}^{\circledR}$ (American Type Culture Collection, Manassas, VA, USA) and cultured in DMEM with Glutamax (Gibco, Darmstadt, Germany) supplemented with 10\%-20\% foetal bovine serum (FBS, Merck KGaA, Darmstadt, Germany) and $1 \%$ antibiotics $\left(100 \mathrm{U} / \mathrm{mL}\right.$ penicillin and $100 \mu \mathrm{g} / \mathrm{mL}$ streptomycin) at $37{ }^{\circ} \mathrm{C}$ in a humidified incubator under $5 \% \mathrm{CO}_{2}$. After reaching $80 \%$ confluence, the cells were subcultured in 96-well plates at a final concentration of $10 \times 10^{4}$ cells $/ \mathrm{mL}(100 \mu \mathrm{L}$ medium in each well).

\subsection{Cytotoxicity Assay}

To estimate the cytotoxicity of extracts against three cell lines, MTT (3-[4,5-diethylthiazol2-yl]-2,5-diphenyltetrazolium bromide) and a slightly modified method by Mosmann [34] were used. Cells were seeded in 96-well plates at a final concentration of $10 \times 10^{4}$ cells $/ \mathrm{mL}$ (100 $\mu \mathrm{L}$ medium in each well) and incubated overnight for adherence. Then, $100 \mu \mathrm{L}$ of medium or extract dilution in medium $(100 \mu \mathrm{g} / \mathrm{mL}-1200 \mu \mathrm{g} / \mathrm{mL})$ was added to each well. The medium with the tested extracts was added at different concentrations. After $24 \mathrm{~h}$ incubation with the extracts, the medium was exchanged with $100 \mu \mathrm{L}$ of MTT solution $\left(1 \mathrm{mg} / \mathrm{mL}\right.$ in PBS) and incubated for $2 \mathrm{~h}$ at $37^{\circ} \mathrm{C}$. Thereafter, the solution was aspirated, and isopropanol was added to each well to dissolve the formazan crystals formed during the incubation period. The plate was placed in a shaker for dissolution. The absorbance was determined spectrophotometrically at $570 \mathrm{~nm}$ using a reference wavelength of $650 \mathrm{~nm}$ on a Hidex Sense microplate reader (Hidex, Turku, Finland).

\subsection{Statistical Analysis}

The data obtained from the biological activity assay were analysed using the log (inhibitor) vs. response-variable slope (four parameters) analysis function and performed with GraphPad Prism (GraphPad, Inc., La Jolla, CA, USA) computer software. IC $5_{50}$ values were obtained from three independent experiments $(n=6)$ and are presented as the means $\pm \mathrm{SD}$. The quantitative results (content of flavonoids and alkaloids) are presented as the mean \pm standard deviation (SD). Statistical analysis was performed using Student's $t$-test (two tailed distribution, two sample equal variances). $p<0.05$ was considered statistically significant. 


\section{Conclusions}

The total content of alkaloids in aqueous ethanol extracts prepared from cultivated C. majus specimens was higher than that observed in extracts prepared from wild-grown plant material. Chelidonine, sanguinarine, and chelerythrine were the main contributors to the total increase in alkaloid content. The cultivation of $C$. majus did not significantly affect the total content of flavonol glycosides. The observed differences in the phytochemical compositions of the C. majus extracts resulted in significant increases in the cytotoxic activities of the preparations.

Supplementary Materials: The following are available online at https:/ / www.mdpi.com/article/ 10.3390/plants10091971/s1, Table S1: Content of alkaloids ( $\mu \mathrm{g} / \mathrm{g}$ of dry material) in aqueous ethanol extracts of wild and cultivated C. majus specimen, Table S2: Content of flavonoid ( $\mu \mathrm{g} / \mathrm{g}$ of dry material) in aqueous ethanol extracts of wild and cultivated C. majus specimen, Table S3 Collection site and geographical coordinates of Chelidonium majus populations, Table S4: MRM parameters applied for the analysis of alkaloids in C. majus extracts, Table S5: MRM parameters applied for the analysis of flavonoid glycoside in C. majus extracts, Figure S1: Flavonoid aglycone extracted mass chromatograms (parent search): kaempferol (a), quercetin (b), isorhamnetin (c). Peak identification in Table 3, Figure S2. Correlations between IC50 values of cytotoxic activities of $C$. majus extracts measured by MTT assay in three cell lines (CaCo-2, B16-F10 and HepG-2) and concentration of the alkaloids identified in the extracts by liquid chromatography-tandem mass spectrometry. The data were analysed by the Pearson's correlation test using GraphPad Prism 8.0. Statistically significant correlations are shown in the figure. A value of $p<0.05$ was considered to be statistically significant.

Author Contributions: Conceptualization, M.D. and S.G., methodology, V.K., A.K., I.N. and I.S.; writing — original draft preparation, V.K., I.S. and S.G., writing—review and editing, I.S., I.M., M.D. and O.P. All authors have read and agreed to the published version of the manuscript.

Funding: This research was funded by European Regional Development Fund project "Innovative solutions for growing technologies and applications of spring medicinal and aromatic plants" (Grant No. 1.1.1.1/18/A/ 043).

Data Availability Statement: Data available on request.

Conflicts of Interest: The authors declare no conflict of interest.

\section{References}

1. Zielinska, S.; Jezierska-Domaradzka, A.; Wójciak-Kosior, M.; Sowa, I.; Junka, A.; Matkowski, A.M. Greater Celandine's Ups and Downs-21 Centuries of Medicinal Uses of Chelidonium Majus from the Viewpoint of Today's Pharmacology. Front. Pharmacol. 2018, 9, 299. [CrossRef] [PubMed]

2. Priedītis, N. Latvijas Augi [Plants in Latvia]; Riga, Gandrs, 2014; p. 888.

3. Gilca, M.; Gaman, L.; Panait, E.; Stoian, I.; Atanasiu, V. Chelidonium Majus-An Integrative Review: Traditional Knowledge versus Modern Findings. Forsch. Komplementarmed. 2010, 17, 241-248. [CrossRef] [PubMed]

4. Biswas, S.J. Chelidonium Majus L.- A Review on Pharmacological Activities and Clinical Effects. J. Med. Plants. 2013, 2, $238-245$. [CrossRef]

5. Barnes, J.; Anderson, L.; Phillipson, D. The monograph: Celandine, Greater. In Herbal Medicines: A Guide for Healthcare; Pharmaceutical Press: London, UK, 2007; pp. 136-145.

6. Sile, I.; Romane, E.; Reinsone, S.; Maurina, B.; Tirzite, D.; Dambrova, M. Data on Medicinal Plants in the Records of Latvian Folk Medicine from the 19th Century. J. Ethnopharmacol. 2020, 28, 105024. [CrossRef] [PubMed]

7. Kujawska, M.; Klepacki, P.; Łuczaj, Ł. Fischer's Plants in Folk Beliefs and Customs: A Previously Unknown Contribution to the Ethnobotany of the Polish-Lithuanian-Belarusian Borderland. J. Ethnobiol. Ethnomed. 2017, 13, 1-15. [CrossRef] [PubMed]

8. Menković, N.; Šavikin, K.; Tasić, S.; Zdunić, G.; Stešević, D.; Milosavljević, S.; Vincek, D. Ethnobotanical Study on Traditional Uses of Wild Medicinal Plants in Prokletije Mountains (Montenegro). J. Ethnopharmacol. 2011, 133, 97-107. [CrossRef] [PubMed]

9. Fortini, P.; di Marzio, P.; Guarrera, P.M.; Iorizzi, M. Ethnobotanical Study on the Medicinal Plants in the Mainarde Mountains (Central-Southern Apennine, Italy). J. Ethnopharmacol. 2016, 184, 208-218. [CrossRef] [PubMed]

10. Pranskuniene, Z; Dauliute, R.; Pranskunas, A.; Bernatoniene, J. Ethnopharmaceutical knowledge in Samogitia region of Lithuania: Where old traditions overlap with modern medicine. J. Ethnobiol. Ethnomed. 2018, 14, 1-26. [CrossRef]

11. European Medicines Agency. Public Statement on Chelidonium Majus L., Herba. Available online: https:/ /Www.Ema.Europa. Eu/En/Documents/Public-Statement/Final-Public-Statement-Chelidonium-Majus-1-Herba_en.Pdf (accessed on 30 July 2021). 
12. Och, A.; Zalewski, D.; Komsta, Ł.; Kołodziej, P.; Kocki, J.; Bogucka-Kocka, A. Cytotoxic and Proapoptotic Activity of Sanguinarine, Berberine, and Extracts of Chelidonium Majus L. and Berberis Thunbergii DC. toward Hematopoietic Cancer Cell Lines. Toxins 2019, 11, 485. [CrossRef]

13. Deljanin, M.; Nikolic, M.; Baskic, D.; Todorovic, D.; Djurdjevic, P.; Zaric, M.; Stankovic, M.; Todorovic, M.; Avramovic, D.; Popovic, S. Chelidonium Majus Crude Extract Inhibits Migration and Induces Cell Cycle Arrest and Apoptosis in Tumor Cell Lines. J. Ethnopharmacol. 2016, 190, 362-371. [CrossRef]

14. Rica Capistrano, I.; Wouters, A.; Lardon, F.; Gravekamp, C.; Apers, S.; Pieters, L. In Vitro and in Vivo Investigations on the Antitumour Activity of Chelidonium Majus. Phytomed 2015, 22, 1279-1287. [CrossRef]

15. Ernst, E.; Schmidt, K. Ukrain-A New Cancer Cure? A Systematic Review of Randomised Clinical Trials. BMC Cancer 2005, 5, 1-7. [CrossRef]

16. Grosso, C.; Ferreres, F.; Gil-Izquierdo, A.; Valentão, P.; Sampaio, M.; Lima, J.; Andrade, P.B. Box-Behnken Factorial Design to Obtain a Phenolic-Rich Extract from the Aerial Parts of Chelidonium Majus L. Talanta 2014, 130, 128-136. [CrossRef]

17. Maji, A.K.; Banerji, P. Chelidonium Majus L. (Greater Celandine)—A Review on Its Phytochemical and Therapeutic Perspectives. Int. J. Herb. Med. 2015, 3, 10-27. [CrossRef]

18. Seidler-Łożykowska, K.; Kędzia, B.; Bocianowski, J.; Gryszczyńska, A.; Łowicki, Z.; Opala, B.; Pietrowiak, A. Content of Alkaloids and Flavonoids in Celandine (Chelidonium Majus L.) Herb at the Selected Developmental Phases. Acta Sci. Pol. Hortorum Cultus. 2016, 15, 161-172.

19. Wianowska, D.; Garbaczewska, S.; Cieniecka-Roslonkiewicz, A.; Typek, R.; Dawidowicz, A.L. Chemical Composition and Antifungal Activity of Chelidonium Majus Extracts-Antagonistic Action of Chelerythrine and Sanguinarine against Botrytis Cinerea. Chem. Ecol. 2018, 34, 582-594. [CrossRef]

20. Jesionek, W.; Fornal, E.; Majer-Dziedzic, B.; Móricz, Á.M.; Nowicky, W.; Choma, I.M. Investigation of the Composition and Antibacterial Activity of Ukrain ${ }^{\mathrm{TM}}$ Drug Using Liquid Chromatography Techniques. J. Chromatogr. A 2016, 1429, 340-347. [CrossRef]

21. Sárközi, Á.; Janicsák, G.; Kursinszki, L.; Kéry, Á. Alkaloid Composition of Chelidonium Majus L. Studied by Different Chromatographic Techniques. Chromatographia 2006, 63, 81-86. [CrossRef]

22. Zielinska, S.; Wójciak-Kosior, M.; Dziagwa-Becker, M.; Glensk, M.; Sowa, I.; Fijalkowski, K.; Ruranska-Smutnicka, D.; Matkowski, A.; Junka, A. The Activity of Isoquinoline Alkaloids and Extracts from Chelidonium Majus against Pathogenic Bacteria and Candida Sp. Toxins 2019, 11. [CrossRef]

23. Zielínska, S.; Czerwínska, M.E.; Dziagwa-Becker, M.; Drys, A.; Kucharski, M.; Jezierska-Domaradzka, A.; Płachno, B.J.; Matkowski, A. Modulatory Effect of Chelidonium Majus Extract and Its Alkaloids on LPS-Stimulated Cytokine Secretion in Human Neutrophils. Molecules 2020, 25, 842. [CrossRef]

24. Jakovljević, Z.D.; Stanković, S.M.; Topuzović, D.M. Seasonal Variability of Chelidonium Majus L. Secondary Metabolites Content and Antioxidant Activity. EXCLI J. 2013, 12, 260-268. [CrossRef]

25. Qing, Z.X.; Cheng, P.; Liu, X.b.; Liu, Y.S.; Zeng, J.G. Systematic Identification of Alkaloids in Macleaya Microcarpa Fruits by Liquid Chromatography Tandem Mass Spectrometry Combined with the Isoquinoline Alkaloids Biosynthetic Pathway. J. Pharm. Biomed. Anal. 2015, 103, 26-34. [CrossRef]

26. Orvos, P.; Virág, L.; Tálosi, L.; Hajdú, Z.; Csupor, D.; Jedlinszki, N.; Szél, T.; Varró, A.; Hohmann, J. Effects of Chelidonium Majus Extracts and Major Alkaloids on HERG Potassium Channels and on Dog Cardiac Action Potential—A Safety Approach. Fitoterapia 2015, 100, 156-165. [CrossRef] [PubMed]

27. Tomè, F.; Colombo, M.L. Distribution of Alkaloids in Chelidonium Majus and Factors Affecting Their Accumulation. Phytochemistry 1995, 40, 37-39. [CrossRef]

28. Samatadze, T.E.; Yurkevich, O.Y.; Hazieva, F.M.; Konyaeva, E.A.; Morozov, A.I.; Zoshchuk, S.A.; Amosova, A.V.; Muravenko, O.V. Agro-Morphological, Microanatomical and Molecular Cytogenetic Characterization of the Medicinal Plant Chelidonium Majus L. Plants 2020, 9, 1396. [CrossRef] [PubMed]

29. Parvu, M.; Vlase, L.; Fodorpataki, L.; Parvu, O.; Rosca-Casian, O.; Bartha, C.; Barbu-Tudoran, L.; Parvu, A.E. Chemical Composition of Celandine (Chelidonium Majus L.) Extract and Its Effects on Botrytis Tulipae (Lib.) Lind Fungus and the Tulip. Not. Bot. Horti Agrobot. Cluj Napoca 2013, 41, 414-426. [CrossRef]

30. Lin, L.Z.; Chen, P.; Ozcan, M.; Harnly, J.M. Chromatographic Profiles and Identification of New Phenolic Components of Ginkgo Biloba Leaves and Selected Products. J. Agric. Food Chem. 2008, 56, 6671-6679. [CrossRef] [PubMed]

31. El-readi, M.Z.; Eid, S.; Lotfy, M.; Tahrani, A.; Wink, M. Modulation of Multidrug Resistance in Cancer Cells by Chelidonine and Chelidonium Majus Alkaloids. Phytomedicine 2013, 20, 282-294. [CrossRef]

32. Fadhil, Y.B.; Alsammarraie, K.W.; Mohaimen, N.A.; Mohammed, Z.Y. In Vitro Cytotoxic Activity of Chelidonium Majus Extract Using Different Types of Cell Lines. Int. J. Curr. Microbiol. Appl. Sci. 2018, 7, 1767-1775. [CrossRef]

33. Petruczynik, A.; Tuzimski, T.; Plech, T.; Misiurek, J.; Szalast, K. Comparison of Anticancer Activity and HPLC-DAD Determination of Selected Isoquinoline Alkaloids. Molecules 2019, 24, 3417. [CrossRef]

34. Mosmann, T. Rapid Colorimetric Assay for Cellular Growth and Survival: Application to Proliferation and Cytotoxicity Assays. J. Immunol. Methods. 1983, 65, 55-63. [CrossRef] 